\title{
Korelasi Antara Metoda Ceramah Dengan Minat Belajar Terhadap \\ Hasil Belajar Siswa Dalam Mata Pelajaran Ilmu Pengetahuan Sosial Terhadap Keberhasilan Belajar Siswa Di SD Negeri Prabugantungan I dan SD Negeri Prabugantungan 3 Cileles Kabupaten Lebak
}

\author{
Yudawati \\ yudawati@yahoo.com
}

\begin{abstract}
Abstrak
Para siswa yang memiliki hasil rendah. menurut pengamatan diperoleh data sementara bahwa mereka cenderung kurang termotivasi sehingga kurang aktif dalam belajar, sehingga kurang mempunyai apresiasi yang baik pada mata pelajaran tersebut.

Penelitian ini ingin membuktikan pengaruh penggunaan metode ceramah sebagai variabel $\mathrm{X}_{1}$ dan minat belajar sebagai variabel $\mathrm{X}_{2}$ terhadap hasil belajar siswa pada mata pelajaran Ilmu Pengetahuan Sosial sebagai variabel Y. Ketiga variabel mempunyai ciri dan sifat yang berbeda satu sama lain-lainnya, tetapi semua mempunyai keterkaitan dengan proses pemberian Penelitian ini mempunyai kelompok perlakuan dengan penggunaan metode ceramah sebagai variabel bebas dan minat belajar sebagai variabel moderator.

Ada pengaruh hasil belajar antara siswa kelas V SD Negeri Prabugantungan 1 yang menggunakan metode ceramah dengan siswa kelas V SD Negeri Prabugantungan 2 yang tidak menggunakan metode ceramah. Ada pengaruh hasil belajar antara siswa kelas V SD Negeri Prabugantungan 1 yang memiliki minat belajar lebih tinggi karena proses perbelajaran (tatap muka) menggunakan metode ceramah dengan siswa kelas $\mathrm{V}$ SD Negeri Prabugantungan 2 yang tidak menggunakan metode ceramah sehingga minat belajarnya rendah.

Bahwa dengan penggunaan metode ceramah, minat belajar siswa meningkat sehingga mempengaruhi hasil belajar. Hal ini dapat dilihat dari hasil pengolahan terhadap data pada lampiran yaitu korelasi antara variabel X terhadap variabel Y. Penggunaan metode ceramah dan minat belajar siswa di SD Negeri Prabugantungan 1 dan SD Negeri Prabugantungan 3 dapat mempengaruhi hasil belajar siswa.
\end{abstract}

Kata kunci: Metode ceramah, minat belajar, keberhasilan belajar

\section{PENDAHULUAN}

Dilihat dari kacamata para pakar bahwa pendidikan di Indonesia adalah masih rendahnya mutu para lulusan jalur sekolah, baik negeri maupun swasta. Masalah ini terus menjadi sorotan mengingat proses pendidikan formal dan non formal di Indonesia mempunyai andil yang cukup besar bagi keberhasilan pembangunan nasional secara keseluruhan. Karena, keberhasilan pembangunan tidak terlepas dengan sumber daya manusia yang berkualitas, dan pendidikan 
memegang peranan yang sangat penting dalam proses peningkatan kualitas sumber daya manusia.

Umaedi mengatakan bahwa peningkatan kualitas pendidikan merupakan proses yang terintegrasi dengan proses peningkatan kualitas sumber daya manusia itu sendiri. Menyadari pentingnya proses peningkatan kualitas sumber daya manusia, maka pemerintah bersama kalangan swasta sama-sama telah dan terus berupaya mewujudkan amanat tersebut melalui berbagai usaha pembangunan pendidikan yang lebih berkualitas antara lain melalui pengembangan dan perbaikan kurikulum dan sistem evaluasi, perbaikan sarana pendidikan, pengembangan dan pengadaan materi ajar, serta pelatihan bagi guru dan tenaga kependidikan lainnya. Namun demikian, upaya tersebut belum dapat menunjukkan hasil yang signifikan. Salah satu indikasi bahwa upaya tersebut belum memuaskan adalah hasil belajar (perolehan nilai) siswa untuk berbagai bidang studi pada jenjang SD, SLTP dan SLTA yang tidak menunjukkan kenaikan yang berarti bahkan dapat dikatakan konstan dari tahun ke tahun, kecuali pada beberapa sekolah dengan jumlah yang relatif kecil (Umaedi, 1999).

Pendapat di atas menggambarkan pendidikan sebagai suatu proses merupakan suatu sistem yang ditopang oleh berbagai kemampuan sumber daya pendidikan sebagai komponen proses yang saling mempunyai keterkaitan. Dengan demikian, satu saja komponen pembentuk sistem tidak berfungsi dengan baik, maka proses pendidikan pun akan sulit memperoleh output untuk dapat membawa ke arah tujuan yang diinginkan. Sistem pendidikan harus semua komponen proses berjalan secara padu tanpa ada satupun yang tidak saling menunjang sehingga kemampuan pendidikan tidak mengalami distrosi.

Anak didik (siswa) merupakan salah satu komponen proses penting dari sistem pendidikan. Begitu pentingnya kedudukan anak didik tersebut, sehingga Mujawir (1969) menyebutnya sebagai subjek pendidikan dan pengajaran yang paling menentukan di samping faktor kurikulum dan lingkungan. Proses pendidikan formal melalui kegiatan belajar di rumah dan di sekolah. Oleh karena itu tidak heran bila dalam beberapa dekade terakhir banyak bermunculan teori-teori tentang belajar yang digagas para pakar psikologi pendidikan (Bigge, 1982) yang pada dasarnya merupakan hasil penelitian terhadap sifat-sifat dan potensi manusia yang menjadi subjek pendidikan dalam rangka mengoptimalkan keberhasilan proses belajar mengajar itu sendiri (Bigge, 1982).

Terkait dengan proses belajar anak didik (siswa) di atas, juga dialami di SD Negeri Prabugantungan I dan SD Negeri Prabugantungan 3 Cileles Kabupaten Lebak dalam mata pelajaran Ilmu Pengetahuan Sosial. Para siswa yang memiliki hasil Ilmu Pengetahuan Sosial baik diduga kuat memiliki minat yang tinggi terhadap mata pelajaran 
tersebut. Hal ini terlihat dengan apresiasi mereka yang cukup tinggi terhadap mata pelajaran tersebut. Kelompok ini juga didukung oleh kemampuan guru dalam kegiatan belajar mengajar yang mampu menciptakan suasana demokratis, dinamis dan kondusif bagi poses transformasi nilai-nilai yang baik.

Para siswa yang memiliki hasil rendah. menurut pengamatan diperoleh data sementara bahwa mereka cenderung kurang termotivasi sehingga kurang aktif dalam belajar, sehingga kurang mempunyai apresiasi yang baik pada mata pelajaran tersebut. Hal itu mungkin berkaitan dengan masalah intensitas minatnya yang rendah sehingga hasil belajarnya sangat kurang untuk tidak dikatakan nihil. Pengamatan penulis terhadap kelompok ini adalah belum cocoknya para siswa dengan metode yang digunakan guru yaitu metode ceramah setiap kali tatap muka pelajaran sehingga cenderung membosankan dan kurang kondusif untuk merangsang siswa mempelajari mata pelajaran.

Dari berbagai penelitian yang dilakukan oleh para ahli, membuktikan bahwa minat memiliki pengaruh yang positif terhadap keberhasilan belajar siswa, begitu juga kaitannya dengan metode pengajaran yang digunakan oleh guru, banyak siswa yang secara kognitif tergolong sedang, namun karena termotivasi dengan cara mengajar guru, maka mereka mampu menunjukkan hasil yang optimal.

Berdasarkan fenomena yang diuraikan di atas, penulis tertarik untuk melakukan penelitian secara ilmiah, tentang sejauhmana pengaruh minat dan metode pengajaran guru terhadap hasil belajar (perolehan nilai) siswa SD Negeri Prabugantungan I dan SD Negeri Prabugantungan 3 Cileles Kabupaten Lebak dalam mata pelajaran Ilmu Pengetahuan Sosial?

\section{METODE}

Penelitian ini merupakan penelitian eksperimen. Ada tiga unsur penting dalam pelaksanaan suatu eksperimen: pertama, pengendalian. Pengendalian adalah inti metode eksperimen. Tanpa pengendalian kita tidak mungkin dapat menilai secara tegas pengaruh variable bebas. Tujuan pengendalian dalam eksperimen adalah untuk mengatur situasi sehingga pengaruh variable dapat diselidiki.

Kedua, manipulasi. Manipulasi suatu variable menunjuk pada tindakan yang sengaja dilakukan oleh peneliti. Dalam penelitian ini, pemanipulasian variable mempunyai bentuk khas dimana peneliti memberikan seperangkat kondisi yang bermacammacam dan yang telah ditentukan sebelumnya kepada subyek.

Ketiga, pengamatan. Pengamatan dilakukan terhadap cirri-ciri tingkah laku subyek yang diteliti. Pengamatan yang sedapat mungkin bersifat kuantitas itulah variable terikatnya. Variable terikat dalam penelitian sering berupa hasil dari sesuatu.

Penelitian ini ingin membuktikan pengaruh penggunaan metode ceramah sebagai variabel $\mathrm{X}_{1}$ dan minat belajar sebagai variabel $\mathrm{X}_{2}$ terhadap hasil 
belajar siswa pada mata pelajaran Ilmu Pengetahuan Sosial sebagai variabel Y. Ketiga variabel mempunyai ciri dan sifat yang berbeda satu sama lain-lainnya, tetapi semua mempunyai keterkaitan dengan proses pemberian Penelitian ini mempunyai kelompok perlakuan dengan penggunaan metode ceramah sebagai variabel bebas dan minat belajar sebagai variabel moderator.

Dalam penelitian eksperimen sekurangnya ada sebuah variabel yang dimanipulasi untuk diuji pengaruhnya terhadap variabel terikat (Gay, 1987). Misalnya pendekatan pemberian atau perlakuan tertentu yang dalam proses pemberian. Perlakuan tertentu yang diuji pengaruhnya terhadap variabel terikat disebut variabel bebas. Dalam penelitian ini disajikan variabel bebas yaitu penggunaan metode ceramah. Dengan demikian, satu kelompok siswa diberi perlakuan (dalam kegiatan pembelajaran) dengan menggunakan metode ceramah dan satu kelompok siswa yang diberi perlakuan dengan pendekatan konvensional.

Variabel moderator yaitu minat belajar diukur dan diklasifikasikan untuk mengetahui apakah ada interaksinya antara variabel bebas dengan variabel moderator terhadap variabel terikat. Minat belajar (diklasifikasikan menjadi dua yaitu minat belajar tinggi dan minat belajar rendah, dan diukur dengan tes minat belajar dengan menggunakan skala Likert. Variabel tergantung dalam penelitian ini adalah perolehan hasil belajar untuk bidang studi Ilmu Pengetahuan Sosial yang menekankan pada kategori pemahaman kognitif. Pada pelaksanaannya penelitian ini menempuh prosedur kegiatan yakni pengukuran tingkat minat belajar, partes, perlakuan (pemberian dengan menggunakan metode ceramah dan konvensional), diakhiri dengan tes perolehan hasil belajar. Pengukuran tingkat minat belajar dilakukan pada pertemuan untuk masing-masing kelompok.

Pengukuran minat belajar melibatkan 70 siswa yang menjadi subyek penelitian. yaitu 35 siswa kelompok ceramah dan 35 siswa kelompok konvensional. Untuk membagi kelas menjadi dua kelompok dilakukan dengan memilih dua sekolah yang berbeda dimana kelompok ceramah dan kelompok konvensional di SD Negeri Prabugantungan 1 dan SD Negeri Prabugantungan 2 Kecamatan Cileles Kabupaten Lebak. Setelah tahap pembagian kelas dilakukan, selanjutnya siswa pada kelompok A dan kelompok B diberikan pra-tes untuk mengetahui kemampun awal siswa terhadap cakupan isi bidang studi yang dikenakan perlakuan. Setelah pra-tes dilakukan, masing-masing kelompok diberi perlakuan yang berbeda selama pelaksanaan penelitian. Setelah perlakuan selesai, kelompok subyek diberi post tes, yaitu untuk mengukur perolehan belajar yang dijadikan variabel terikat.

Populasi terjangkau dalam penelitian ini adalah siswa SD Negeri Prabugantungan 1 Kecamatan Cileles Kabupaten Lebak, sedangkan sampel penelitiannya adalah siswa SD Negeri 
Prabugantungan 2 Kecamatan Cileles

Kabupaten Lebak dan kedua sample sekolah tersebut diambil secara purposive. Pengambilan sampel dengan pertimbangan bahwa sudah dianggap mengerti untuk menjawab angket yang diberikan dan tidak akan mengganggu konsentrasi siswa dalam belajar karena tidak sedang menghadapi ujian. Jumlah siswa kelas $\mathrm{V}$ pada dan SD Negeri Prabugantungan 1 dan SD Negeri Prabugantungan 2 Kecamatan Cileles Kabupaten Lebak jumlahnya sama yakni 35 siswa, sehingga responden dalam penelitian ini berjumlah 70 orang.

Variabel penelitian ini terdiri dari (1) variabel bebas, yaitu variabel perlakuan dan diprediksi sebagai sebab yang mempengaruhi pada variabel terikat, (2) Variabel moderator, yaitu variabel yang tidak dimanipulasi, yang diprediksi memiliki pengaruh untuk mengubah hubungan antara variabel bebas dan variabel terikat, (3) Variabel terikat, yaitu variabel yang diprediksi akan muncul sebagai akibat dari variabel bebas dan, (4) Variabel kontrol, yaitu variabel yang diprediksi ikut memberi pengaruh terhadap variabel terikat tetapi diupayakan konstan.

Varibel bebas dalam penelitian ini adalah penggunaan metode ceramah, sedangkan variabel moderator adalah minat belajar siswa. Minat ini dibedakan menjadi dua kategori yakni minat belajar tinggi dan minat belajar rendah. Variabel terikat dalam penelitian ini adalah hasil belajar siswa pada mata pelajaran Ilmu Pengetahuan Sosial. Variabel-variabel yang tidak dimanipulasi, tetap diprediksi dapat memberi pengaruh terhadap perolehan belajar, atau diduga ikut mempengaruhi kesahihan eksternal eksperimen ini, diupayakan kostan. Variabel-variabel yang diidentifikasi termasuk dalam kelompok ini adalah karakteristik subyek selain minat belajar, misalnya: kemampuan awal yang dimiliki oleh subyek penelitian terhadap isi mata peiajaran, kondisi pelaksanaan perlakuan, tepat perlakuan, dan keadaan kelas, diperlakukan sama untuk tiap-tiap kelompok yang dilibatkan dalam penelitian ini.

Dalam hal ini akan dibicarakan tentang cara mengukur variabel minat belajar, kemampuan awal lewat pra-tes dan pengukuran perolehan hasil belajar Ilmu Pengetahuan Sosial pada bagian ini akan diuraikan seperangkat tes yang dipakai dengan cara pemberian skor. Pengukuran minat belajar dilakukan setelah kelompok perlakuan mempelajari Ilmu Pengetahuan Sosial.

Kemampuan awal dari subyek diukur dengan memakai pra-tes. Bentuk tes yang digunakan adalah tes isian (melengkapi) Sedangkan tes pengolahan data untuk keperluan pengujian hipotesis adalah tes bentuk pilihan ganda dengan jumlah 40 soal, setiap butir diberi bobot 2.5 sehingga skor maksimal ideal 100 dan skor minimal ideal 2,5. Data yang dijaring melalui kegiatan penelitian disesuaikan dengan rumusan masalah yang telah dicantumkan di atas. Kegiatan pemberian yang akan diamati adalah pemberian/pengkajian yang berkaitan dengan minat belajar. Kegiatan yang diteliti adalah kegiatan pemberian 
dengan metode ceramah yang tidak terikat dengan ketentuan/aturan, namun semata-mata didorong oleh rasa tanggung jawab moral guru untuk menerapkan kemampuan guru dalam mengelola kelas.

Dalam kegiatan penelitian ini sumber data dapat berupa orang, diantaranya kepala sekolah, guru, karyawan TU dan siswa, sumber data peristiwa yang diperoleh dengan menerapkan metode observasi partisipasi sebagimana tercantum pada rumusan masalah, sumber data berupa benda yang diperoleh melalui metode dokumenetasi yaitu dengan mengutif sejumlah dokumen yang tersedia pada lembaga pendidikan dalam kaitan dengan kegiatan pengkajian minat belajar dan pemberian melalui metode ceramah dan konvensional.

Pengumpulan data penelitian dilakukan dengan menyebarkan angket terhadap responden yang telah terpilih sebagai sampel. Kuesioner dimintai untuk diisi tanpa harus berdiskusi dengan responden lain. Setelah seluruh angket ditarik, maka seterusnya dicatat dalam rangka menganalisis data. Teknik analisis data ini meliputi uji persyaratan analisis data sebagai prasyarat penggunaan teknik analisis dan teknik pengujian hipotesis dalam perhitungan korelasi.

\section{Uji Persyaratan Analisis}

Uji persyaratan analisis yang digunakan dalam penelitian ini terdiri dari uji normalitas data, uji linearitas dan keberartian regresi.

2. Uji Normalitas Data.

Uji ini dimaksudkan untuk menentukan normal tidaknya

distribusi data penelitian. Uji normalitas data yang digunakan adalah uji "chi square". Data dinyatakan normal bila harga $\chi^{2}$ hitung $<\chi^{2}$ tebel. Diuji pada taraf signifikansi 0,05.

3. Uji Linearitas Data

Uji ini dimaksudkan untuk melihat apakah regresi (bentuk linear) yang diperoleh ada artinya jika digunakan untuk membuat kesimpulan mengenai hubungan antar beberapa variabel yang sedang dianalisis. Regresi linear dinyatakan berarti apabila harga $F$ hitung < F tabel. Diuji pada taraf signifikansi 0,05.

\section{Analisis Data}

Teknik analisis yang relevan untuk menguji hipotesis 1 dan 2 adalah regresi dan korelasi sederhana. Sedangkan hipotesis ketiga diuji dengan analisis regresi dan korelasi ganda.

Setelah hipotesis diuji maka pengujian diperdalam dengan menentukan keberartian korelasi antara masing-masing dan keseluruhan variabel bebas terhadap variabel terikat dengan uji $t$ dan uji $F$. Keberartian korelasi tersebut ditentukan dengan menentukan koefisien determinasi $\left(R^{2}\right.$ y.1.2). Keberartian korelasi ini dimaksudkan untuk menentukan besarnya konstribusi variabel bebas terhadap variabel terikat, baik secara sendiri-sendiri atau bersama-sama.

Dalam analisis data bagian terakhir perhitungan korelasi parsial dengan mengkorelasikan setiap variabel 
bebas dengan variabel terikat. Uji ini dimaksudkan untuk meyakinkan pada pengujian korelasi sebelumnya dan sebagai pengecekan kembali dengan metode korelasi parsial ini. Korelasi parsial dimaksudkan untuk melihat kontribusi murni variabel bebas terhadap terikat dengan $\mathrm{X}_{1}\left(\mathrm{r}_{\mathrm{y} 1.2}\right)$ maka $\mathrm{X}_{2}$ dikontrol, dan apabila $\mathrm{Y}$ dikorelasikan dengan $\mathrm{X}_{2}\left(\mathrm{r}_{\mathrm{y} 2.1}\right)$ maka $\mathrm{X}_{1}$ dikontrol. Sedangkan keberartian korelasinya dilihat dari membandingkan $\mathrm{t}$ hitung $>\mathrm{t}$ tabel.

\section{HASIL}

1. Hasil belajar siswa yang menggunakan metode ceramah (data eksperimen)

Hasil pengumpulan data hasil belajar dengan menggunakan metode ceramah untuk hasil belajar (lampiran 4) diperoleh skor tertinggi $=85$ dan skor terendah $=50$ dengan nilai ratarata $=77.67$ clan standar deviasinya $(S D)=11,2$. Disamping itu juga dicari ratarata ideal (Mi) dan standar deviasi ideal (SDi) guna pengkatagorian data. Adapun rumus untuk menentukan besarnya rata-rata ideal (Mi) $1 / 2$ (skor maksimal ideal skor minimal ideal ) dan untuk standar deviasi ideal $(\mathrm{SDi})=1 / 6$ (skor maksimal ideal skor minimal ideal).

Hasil instrumen ditetapkan bahwa skor maksimal ideal $=100$ dan skor minimal ideal $=0$, sehingga $\mathrm{Mi}={ }^{\prime} 1 / 2(.100-0)=50$ dan SDi $1 / 6($ $100-0)=16,67$. Dengan demikian

$\begin{array}{ll}\text { maka dibuat } & \text { untuk } \\ \text { pengkatagorian skornya } & \text { adalah } \\ \text { sebagai berikut: } & \end{array}$

$\begin{array}{lll}\text { Mi+1 Sdi } & \text { sampai } & \text { Mi + 3 SDi = kat } \\ 50+16,67 & & 50+3(16,67) \\ 66,67 & & 10 \\ \text { Mi-1 Sdi } & \text { sampai } & <\text { Mi+1 Sdi }=\text { ka } \\ 50-1(16,67) & & 50+1(16,67) \\ 33.3 & & 66,67 \\ \text { Mi - 3Sdi } & \text { sampai } & <. \text { Mi }- \text { Sdi }- \text { Kat } \\ 50-3(16,7) & & \text { Mi } 1 \text { Sdi kateor } \\ 0 & & 50-1(16,7) \\ & & 33,3\end{array}$

Jadi berdasarkan rata-rata yang diperoleh di atas 72,32 clan 68,73 untuk kelompok eksperimen yaitu data tentang penggunaan metode ceramah pada hasil belajar secara umum dapat digolongkan dalam kategori tinggi.

2. Hasil belajar tanpa menggunakan metode ceramah (data kelompok kontrol)

Hasil pengumpulan data hasil belajar tanpa menggunakan metode ceramah untuk hasil belajar (lampiran 7) diperoleh skor tertinggi = 90 dan skor terendah $=50$ dengan nilai rata-rata $=68.83$ dan standar deviasinya $(S D)=10,3$, Dengan memperhatikan kategiri diatas maka rata -rata yang diperoleh 68,83 sebagai kelompok kontrol yaitu data tentang hasil belajar tanpa menggunaan metode ceramah pada 
hasil belajar secara umum dapat digolongkan da!am kategori sedang. Ha! ini perlu untuk ditingkatkan oleh guru bidang studi bahasa Indonesia di tempat mengadakan peneltian karena dengan menggunakan media pembelajaran der,gan menggunakan metode ceramah sangat tepat dan cocok untuk digunakan mata pelajaran tersebut.

Untuk lebih jelasnya deskripsi data tentang masing-masing variabe! dapat dilihat pada label berikut :

Tabel 4.1 Pengkategorian Data Hasil

Penelitian
\begin{tabular}{|c|c|c|c|}
\hline $\begin{array}{c}\text { Va } \\
\text { ria } \\
\text { bel }\end{array}$ & $\chi$ & $\begin{array}{c}\text { S } \\
\mathrm{D}\end{array}$ & $\begin{array}{c}\text { Ka } \\
\text { teg } \\
\text { ori }\end{array}$ \\
\hline $\mathrm{X} 1$ & 7 & 1 & $\mathrm{Ti}$ \\
& 1. & 0. & $\mathrm{ng}$ \\
& 6 & 3 & $\mathrm{gi}$ \\
& 6 & 6 & \\
\hline $\mathrm{X} 2$ & 6 & 9. & $\mathrm{Se}$ \\
& 8. & 0 & $\mathrm{da}$ \\
& 8 & 6 & $\mathrm{ng}$ \\
& 3 & & \\
\hline
\end{tabular}

Keterangan:

$\mathrm{X}$, : Kelompok siswa yang menggunakan metode ceramah pada hasil be!ajar

$\mathrm{X}-$ : Kelampok siswa yang tidak metode ceramah pada hasil belajar

\section{B. Pengujian Hipoteis}

1. Uji Persyaratan Analisis

Uji persyaratan analisia merupakan suatu syarat yang harus dipenuhi agar analisis regresi dapat dilakukan, baik untuk kepentingan prediksi maupun untuk pengujian hipotesis. Tiga sparat yang harus dipenuhi sebelum melakukan analisis regresi, baik regresi linear sederhana maupun regresi ganda, yaitu: (1) uji normalitas dengan galat taksiran $(\mathrm{Y}-\mathrm{Y})$ dari suatu regresi sederhana. (2) uji homoaenitas varians kelomnokkelomnok skor Y yang dikelompokkan berdasarkan kesamaan data variabel prediktor (Xi), clan (3) uji linearitas bentuk regresi $\mathrm{Y}$ atas $\mathrm{X}$, untuk regresi sederhana.

Berdasarkan ketiqa persvaratan tersebut terdapat dua persyaratan yang disajikan pengujiannya yaitu pertama uji persyaratan normalitas galat taksiran regresi $\mathrm{Y}$ atas $\mathrm{Xi}$ dengan asumsi bahwa distribusi populasi uanq normal tercermin dari distribusi sampel yang normal pula. Pengujian ini dilakukan karena pengujian hipotesis mensyaratkan bahwa sampel berasal dari populasi yang berdistribusi normal. Kedua uji persyaratan homogenitas varians kelompok-kelompok skor $\mathrm{Y}$ berdasarkan kesamaan data $\mathrm{X}$; sedang uji pada bagian pengujian hipotesis penelitian. Uji persyaratan homogenitas yang mengasumsikan dengan setiap skor variabel bebas (X;) memiliki varians yang homogen.

\section{a. Uji Normalitas Populasi}


Pengujian normalitas galat taksiran regresi $\mathrm{Y}$ atas $\mathrm{X}$; dimaksudkan untuk menguji apakah galat taksiran $\mathrm{Y}$ atas $\mathrm{X}$; atau $(\mathrm{Y}-\mathrm{Y}$ ) berdistribusi normal atau tidak. Ketentuan pengujiannya adalah gafat taksiran $(\mathrm{Y}-\mathrm{Y})$ berdistribusi normal. Jika Ho diterima maka berdistribusi normal. Hipotesis statistik adalah sebagai berikut.

Ho : $(Y-\hat{Y})$ berdistribusi normal , sebaliknya

H1 : $(\mathrm{Y}-\mathrm{Y})$ tidak berdistribusi normal

Pengujian normalitas dilakukan untuk mengetahui normal tidaknya sebaran yang akan dianalisis dengan menggunakan $\mathrm{Uji}$ Liliefors dengan kriteria pengujian:

Ho diterima jika L hitung < L tabel Ho ditolak jika L hitung $>\mathrm{L}$ tabel

Dari hasil pengohan uji normalitas data diperoleh harqa $\mathrm{X} 2$ hitung dan X2 tabel tentang data kelompok eksperimen dan kelompok kontrol terhadap hasil belajar sebagai berikut:

\begin{tabular}{|l|l|c|l|}
\hline Kelompok & $\begin{array}{c}\text { X2 } \\
\text { Hitung }\end{array}$ & $\begin{array}{c}\text { X2 } \\
\text { tabel }\end{array}$ & Kategori \\
\hline Eksperimen & 6.91 & 45.23 & $\mathrm{~N}$ \\
ormal \\
\hline Kontrol & 2.74 & 45.23 & $\mathrm{~N}$ \\
& & & ormal \\
\hline
\end{tabular}

\section{b. Uji Homogenitas Data}

Pengujian

homogenitas, maksudnya adalah menguji homogenitas varians antara kelompok-kelompok skor $\mathrm{Y}$ yang berdasarkan kesamaan nilai X1(X1 dan X2 dalam penelitian ini). Untuk itu pengujian homogenitas varians ini dilakukan dengan uji Barlet. Pengujian ini menggunakan kriteria sebagai berikut :

Ho : diterima jika $\mathrm{F}$ hitung $<\mathrm{F}$ tabel. Ho : ditolak jika $\mathrm{F}$ hitung $>\mathrm{F}$ tabel.

Pada taraf signifikansi alpha 0.05 Terlebih dahulu membuat pengelompokkan data $\mathrm{Y}$ sesuai dengan kesamaan data Xi. kemudian menghitung nilai-nilai.Selanjutnya nilai-nilai tersebut dihitung nilai $\mathrm{F}$, dan hasilnya disebut $\mathrm{F}$ hitung.

Sebagaimana telah diuraikan pada sub bab teknik analisis data pada bab III yaitu teknik uji statistik yang digunakan adalah analisis varian dua jalur, yaitu suatu analisis statistik yang digunakan untuk mengatasi perbedaan nilai variabel terikat yang yang dikategorikan berdasarkan variabel - bebas yaitu penggunaan metode ceramah, serta motivasi belajar siswa setelah diberi perlakuan.Dalam analisis varian tersebut sebagai variabel terikat adalah hasil belajar siswa pada hasil belajar setelah menggunakan metode ceramah Seabagai variabel pengendali adalah motivasi belajar siswa yang dipilih menjadi motivasi belajar tinggi dan motivasi belajar rendah.

\section{c. Uji Beda hasil belajar}

Uji beda post tes hasil belajar antara kelompok eksperimen dan kelompok kontrol adalah diperoleh harga $t$ hitung $=0.382$ dan $\mathrm{t}$ tabe! $=$ 0.0564 sehingga t-hitung $>\mathrm{t}$ tabel. Sesuai dengan kriteria pengujian 
hipotesis bahwa terima Ho jika thitung < t-tabel, terima Ho berarti tidak signifikan, dan sebaliknya tolak Ho jika t-hitung > t-tabel, tolak Ho berarti siqnifiikan. Karena, t-hitunq > t-tabel, maka hipotesis yang diajukan pada bab II yang menyatakan ada pengaruh penggunaan hasil belajar siswa yang menggunakan metode ceramah pada hasil belajar dapat diterima.

\section{d. Teknik Uji Korelasi Product Moment}

Teknik ini digunakan untuk mengetahui pengaruh penggunaan metode ceramah pada hasil belajar terhadap motivasi belajar siswa. Dari hasil analisis data pada lampiran 12 diperoleh harga $r^{\wedge}=0,981$ untuk hasil belajar, dengan $r$ tabel $=0,254$ .pada taraf signifikansi 5\%. Dengan membandingkan harga rxv denean $r$ tabel: maka haraa $r^{\wedge}=0,972 * r$ tabel $=0.235$ sehingga terdapat pengaruh penggunaan pendekatan pembelajaran CTL lerhadap mativasi belajar siswa.

\section{e. Teknik Uji Korelasi Ganda}

Teknik uji korelasi ganda digunakan untuk menqetahui interaksi antara motivasi belajar siswa terhadap hasil belajar setelah menggunakan metode ceramah pada hasil belajar Langkah-langkah pengujiannya adalah:
a) Menentukan korelasi antara hasil belajar terhadap motivasi belajar (rxy)
b) Menentukan harga rxy dan harqa F.

Dari hasis analisis data pada lampiran 12 diperoleh harga $\mathrm{rxy}=$ 0,976 , harga $\mathrm{r} 2=0.944$ dan harga $\mathrm{F}$ hitung= 79.5. Dan F tabel $=18-47$ pada taraf sipnifikansi $5 \%$ dengan $\mathrm{dk}$ pembilang dan $\mathrm{dk}$ penyebut adalah $\mathrm{dk}=\mathrm{n}-1$. Sesuai dengan kriteria yang telah ditentukan bahwa hipotesis nihil (Ho) diterima jika harga $F$ hitung < F tabel, dan hipotesis alternatif ( $\mathrm{Ha}$ ) diterima jika F hitung $>\mathrm{F}$ tabel, Ha diterima berarti hipotesis yang diajukan pada bab II diterima, yaitu terdapat pengaruh antara motivasi belajar siswa terhadap hasil belajar setelah menggunakan metode ceramah pada mata pelajaran bahasa Indonesia dapat diterima.

\section{PEMBAHASAN}

A. Pengaruh Penggunaan metode ceramah terhadap hasil belajar Ilmu Pengetahuan Sosial

Berdasarkan hasil pengolahan data diperoleh bahwa hasil belajar Ilmu Pengetahuan Sosial dengan menggunakan Penggunaan metode ceramah lebih tinggi jika dibandingkan dengan hasil belajar Ilmu Pengetahuan Sosial siswa pada mata pelajaran Ilmu Pengetahuan Sosial tanpa menggunakan Penggunaan metode ceramah hal ini dilihat dari nilai rata-rata kelompok eksperimen clan kelompok kontrol.

Perkembangan nilai mean kelompok eksperimen clan kelompok kontrol di atas dapat dijelaskan bahwa untuk kelompok kontrol nilai rata-rata 68 clan untuk kelompok 
eksperimen nilai rata-rata 71.66 . Adanya perbedaan hasil belajar Ilmu Pengetahuan Sosial antara siswa yang menggunakan Penggunaan metode ceramah dengan yang tidak menggunakan Penggunaan metode ceramah terhadap hasil belajar Ilmu Pengetahuan Sosial mata pelajaran Ilmu Pengetahuan Sosial telah diprediksi sebelumnya. Hal ini dapat diprediksi karena berdasarka teoriteori yang digunakan dalam penelitian ini.

Hal ini tentu ada kaitannya dengan pengaruh penggunaan penggunaan metode ceramah. Di samping model pembelajaran di atas, terdapat pula beberapa faktor yang mempengaruhi belajar dalam hal ini hasil belajar Ilmu Pengetahuan Sosial siswa. Penggunaan metode ceramah merupakan konsep belajar yang membantu guru mengaitkan antara mated yang diajarkannya dengan situasi dunia nyata siswa dan mendorong siswa membuat pengaruh antara pengetahuan yang dimilikinya dengan penerapannya dalam kehidupan mereka sebagai anggota keluarga dan masyarakat. Dengan konsep itu, hasil pembelajaran dihadapkan lebih bermakna bagi siswa. Proses penibelajaran berlangsung Sosialiah dalam bentuk kegiatan siswa bekerja dan mengalami, bukan transfer pengetahuan dari guru ke siswa. (Mujadhid, 2005)

Dikatakan oleh Whardani (2004) bahwa Penggunaan metode ceramah memiliki tujuh komponen utama, yaitu konstruktivisme

(Constructivism), menemukan

(Inquiry), bertanya (Questioning) masyarakat belajar (Learning Community), pemodelan (Modeling), refleksi (Reflection) dan penilaian yang sebenarnya (Authentic Assessment). Sebuah kelas dikatakan menggunakan Penggunaan metode ceramah jika menerapkan ketujuh komponen tersebut dalam pembelajarannya. Dan, untuk melaksanakan hal itu tidak sulit. penggunaan metode ceramah dapat diterapkan dalam kurikulum apa saja, bidang studi apa saja, dan kelas yang bagaimanapun keadaannya.

$$
\text { Dikatakan oleh Mujahid }
$$
(2005) bahwa konstruktivisme (constructivisvism) merupakan landasan berfikir (filosofi) Penggunaan metode ceramah, yaitu bahwa pengetahuan dibangun oleh manusia sedikit demi sedikit, yang hasilnya diperluas melalui konteks yang terbatas (sempit) clan tidak sekonyong-konyong. Pengetahuan bukanlah seperangkat fakta-fakta, konsep, atau kaidah yang siap untuk diambil dan diingat. manusia harus mengkonstruksi pengetahuan itu dan memberi makna melalui pengalaman nyata.

Lebih lanjut Mujahid (2005) mengatakan siswa perlu dibiasakan untuk memecahkan masalah, menemukan sesuatu yang berguna bagi dirinya, clan bergelut dengan ide-ide. Guru tidak akan mampu memberikan semua pengetahuan kepada siswa. Siswa harus 
mengkonstruksikan pengetahuan di benak mereka sendiri. Esensi dari teori konstruktivis adalah ide bahwa siswa harus menernukan dan mentransformasikan suatu informasi kompleks ke situasi lain, dan apabila dikehendaki, informasi itu menjadi milik mereka sendiri.

Dikatakan oleh Hamzah (2005) bahwa pembelajaran harus dikemas menjadi proses "menkonstruksi" bukan "menerima" pengetahuan. dalam proses pembelajaran, siswa membangun sendiri pengetahuan mereka melalui keterlibatan aktif dalam proses belajar dan mengajar. Siswa menjadi pusat kegiatan, bukan guru. Landasan berfikir konstruktivisme agak berbeda dengan pandangan kaum objektivis, yang lebih menekankan pada hasil pembelajaran. Dalam pandangan konstruktivis, strategi "memperoleh" lebih diutamakan dibandingkan seberapa banyak siswa memperoleh dan mengingat pengetahuan.

Pengetahuan

tumbuh

berkembang melalui pengelaman. Pemahaman berkembang semakin dalam dan semakin kuat apabila selalu diuji dengan pengalaman baru. Menurut Piaget dalam Hamzah (2005), manusia memiliki struktur pengetahuan dalam otaknya, seperti kotak-kotak yang masing-masing berisi informasi bermakna yang berbeda-beda. Pengalaman sama bagi beberapa orang akan dimaknai berbeda-beda oleh masing-masing individu clan disimpan dalam kotak yang berbeda. setiap pengalaman baru dihubungkan dengan kotakkotak (struktur pengetahuan) dalam otak manusia tersebut. Struktur pengetahuan dikembangkan dalam otak manusia melalui dua cara, yaitu asimilasi atau akomodasi. asimilasi maksudnya struktur pengetahuan baru dibuat atau dibangun atas dasar struktur pengetahuan yang sudah ada. Akomodasi maksudnya struktur pengetahuan yang sudah ada dimodifikasi untuk menampung dan menyesuaikan dengan hadirnya pengalaman baru.

Oleh karena itu, anak harus dikenalkan pada kehidupan seharihari clan guru juga harus menerapkan filosofi ini dalam pembelajaran sehari-hari, yaitu ketika kita merancang pembelajaran dalam bentuk siswa praktek mengerjakan sesuatu, berlatih secara fisik membuat atlas, mendemonstrasikan, menciptakan ide, clan sebagainya. Mari kita kembangkan cara-cara tersebut lebih banyak dan lebih banyak lagi.Di sisi yang lain, dengan penerapan penggunaan metode ceramah, guru diharapkan bekerja secara profesional, mengajar secara sistematis, dan berdasarkan prinsip didaktik metodik yang berdaya guna dan berhasil guna (efisien dan efektif ). Artinya, Guru dapat merekayasa sistem pembelajaran yang mereka laksanakan secara sistematis, dengan pemikiran mengapa clan bagaimana menyelenggarakan kegiatan pembelajaran aktif. Lambat laun 
penerapan penggunaan metode ceramah pada giliranya akan mencetak guru yang potensial dalam menyesuaikan diri terhadap perubaha lingkungan Sosial dan sosial budaya.

\section{B. Pengaruh minat belajar terhadap hasil} belajar Ilmu Pengetahuan Sosial

Minat belajar sangat erat pengaruhnya dengan kebutuhan clan dorongan yang ada dalarn diri si pembelajar. Seseorang akan terdorong untuk melakukan sesuatu bila dirasakan kebutuhan yang ada pada dirinya menuitfut pemenuhan Selama kebutuhan tersebut belum terpenuhi maka selama itu pula yang bersangkutan belum merasa adanya kepuasan pada dirinya. Rasa belum puas inilah yang senantiasa mendorong seseorang untuk bertindak atau melakukan sesuatu. Kekuatan daya dorong itu akan hilang bila sekiranya yang bersankutan telah menjadi puas karena kebutuhannya telah terpenuhi. Rasa ketidak puasan tersebut akan menimbulkan suasana tidak seimbang dalam batin seseorang, sehingga yang bersangkutan merasa terpanggil utuk memperoleh atau mencapai keseimbangan dalam dirinya. Menurut Maslow, kebutuhan seseorang dapat digolong-golongkan menurut jenjang hirarki, yaitu bahvva kebutuhan yang lebih tinggi menuntut untuk dipenuhi apabila dapat merekayasa sistem pembelajaran yang mereka laksanakan secara sistematis, dengan pemikiran mengapa clan bagaimana menyelenggarakan kegiatan pembelajaran aktif. Lambat laun penerapan penggunaan metode ceramah pada giliranya akan mencetak guru yang potensial dalam menyesuaikan diri terhadap perubaha lingkungan Sosial clan sosial budaya.

Sekirannya kebutuhan yang lebih rendah tingkatnya telah terpenuhi tuntutannya. Maslow menggambarkan jenjang kebutuhan dalam bentuk piramida, yang karenanya disebut dengan "Piramida Kebutuhan Moslow". Dari pendapat ahli tersebut, maka minat belajar sangat dibutuhkan dalam meningkatkan hasil belajar Ilmu Pengetahuan Sosial siswa.

Dari hasil analisa data pada pengujian hipotesis diperoleh bahwa hasil belajar Ilmu Pengetahuan Sosial siswa pada mata pelajaran Ilmu Pengetahuan Sosial setelah menggunakan Penggunaan metode ceramah terhadap variabel motivasi berhasil belajar diperoleh bahwa harga F-hitung -> F-tabel yaitu It $>1,5$ -19,47 pada taraf signifikansi a= 0,05 , berarti terdapat interaksi antara hasil belajar Ilmu Pengetahuan Sosial terhadap minat berhasil belajar siswa pada mata Ilmu Pengetahuan Sosial. Selanjutnya dari rumusan hipotesis alternatif (Ha) yang menyatakan bahwa tercjapat interaksi antara hasil belajar Ilmu Pengetahuan Sosial terhadap motivasi berhasil belajar siswa dapat diterima, Sedangkan 
hipotesis nihil (Ho) yang menyatakan tidak terdapat interaksi antar hasil belajar Ilmu Pengetahuan Sosial terhadap berhasil belajar siswa ditolak.

Penelitian ini dapat menyimpulkan bahwa terdapat pengaruh antara hasil belajar Ilmu Pengetahuan Sosial. Penelitian ini menunjukkan bahwa hasil belajar Ilmu Pengetahuan Sosial siswa setelah menggunakan media pembelajaran metoda yang lainnya dan atlas dapat memberikan pengaruh yang positif terhadap berhasil belajar siswa. Data perolehan tentang hasil belajar Ilmu Pengetahuan Sosial memperlihatkan bahwa pada kelompok eksperimen dengan hasil belajar tinggi, maka minat berhasil belajarnya juga tinggi, dan hasil belaijar rendah berhasil belajar juga rendah.

C. Pengaruh Penggunaan metode ceramah dan minat belajar terhadap hasil belajar Ilmu Pengetahuan Sosial

$$
\text { Hasil belajar Ilmu }
$$

Pengetahuan Sosial antara siswa yang menggunakan Penggunaan metode ceramah dengan yang tidak menggunakan Penggunaan metode ceramah terhadap hasil belajar Ilmu Pengetahuan Sosial mata pelajaran Ilmu Pengetahuan Sosial telah diprediksi sebelumnya. Hal ini dapat diprediksi karena berdasarka teoriteori yang digunakan dalam penelitian ini. terdapat interaksi anatara motivasi belajar siswa terhadap hasil belajar setelah menggunakan metode ceramah pada mata pelajaran bahasa Iilmu pengetahua sosial dapat diterima.

Hal ini tentu ada kaitannya dengan pengaruh penggunaan penggunaan metode ceramah. Di samping model pembelajaran di atas, terdapat pula beberapa faktor yang mempengaruhi belajar dalam hal ini hasil belajar Ilmu Pengetahuan Sosial siswa. Penggunaan metode ceramah merupakan konsep belajar yang membantu guru mengaitkan antara materi yang diajarkannya dengan situasi dunia nyata siswa dan mendorong siswa membuat pengaruh antara pengetahuan yang dimilikinya dengan penerapannya dalam kehidupan mereka sebagai anggota keluarga dan masyarakat. Dengan konsep itu, hasil pembelajaran dihadapkan lebih bermakna bagi siswa. Proses penibelajaran berlangsung Sosialiah dalam bentuk kegiatan siswa bekerja dan mengalami, bukan transfer pengetahuan dari guru ke siswa. (Imam Mujdhid, 2005:1) terdapat interaksi anatara motivasi belajar siswa terhadap hasil belajar setelah menggunakan metode ceramah pada mata pelajaran bahasa Indonesia dapat diterima.

\section{SIMPULAN DAN SARAN \\ Simpulan}

1. Ada pengaruh hasil belajar antara siswa kelas V SD Negeri Prabugantungan 1 yang menggunakan metode ceramah dengan siswa kelas V SD Negeri 
Prabugantungan 2 yang tidak menggunakan metode ceramah.

2. Ada pengaruh hasil belajar antara siswa kelas V SD Negeri Prabugantungan 1 yang memiliki minat belajar lebih tinggi karena proses perbelajaran (tatap muka) menggunakan metode ceramah dengan siswa kelas V SD Negeri Prabugantungan 2 yang tidak menggunakan metode ceramah sehingga minat belajarnya rendah.

3. Bahwa dengan penggunaan metode ceramah, minat belajar siswa meningkat sehingga mempengaruhi hasil belajar. Hal ini dapat dilihat dari hasil pengolahan terhadap data pada lampiran yaitu korelasi antara variabel $\mathrm{X}$ terhadap variabel $\mathrm{Y}$.

4. Penggunaan metode ceramah dan minat belajar siswa di SD Negeri Prabugantungan 1 dan SD Negeri Prabugantungan 3 dapat mempengaruhi hasil belajar siswa.

\section{Saran}

1. Kepada guru yang mengajar kelas $V$ di SD Negeri Prabugantungan 1 dan 2, untuk memahami pokok bahasan ilmu pengetahuan sosial dan hendaknya mengoptimalkan penggunaan metode clan media pembelajaran yang ada. Dan yang mengajar kelas $\mathrm{V}$ di SD Negeri Prabugantungan 1 dan SD Negeri Prabugantungan 3 supaya mengupayakan metode pembelajaran yang lebih atraktif dan dinamis lagi dalam penyampaian materi pelajaran IPS sehingga motivasi belajar siswa bisa lebih meningkat dan memelihara alat/sararta yang sudah ada sehingga pada saat digunakan tidak mengalami masalah sehingga waktu dapat digunakan dengan efektif

2. Kepada kepala sekolah tempat mengadakan penelitian, disarankan agar pasilitas belajar siswa termasuk sarana buku paket, alat peraga dan sarana penunjang belajar lainnya selalu di perhatikan dalam mencapai hasil belajar siswa secara optimal.

3. Hendaknya lebih kreatif dalam menggunakan metode pembelajaran agar lebih menggugah aktivitas dan kreatifitas siswa. Dimana mengupayakan metode pembelajaran yang lebih atraktif dan dinamis lagi dalam sehingga motivasi belajar siswa bisa lebih meningkat

\section{DAFTAR RUJUKAN}

Abin Syamsuddin Makmun. 1996. Psikologi Kependidikan. Bandung: Rosda Karya,

Arikunto Suharsimi. 1990. Prosedur Penelitian Pendidikan; Suatu Pendekatan Praktek. Jakarta: Usaha Nasional.

Atkinson et. al, alih Bahasa Nurjannah Taufiq, 1991. Pengantar Psikologi, Jakarta: Erlangga.

Bigge Moms L. 1982. Learning Theoris for Teachers.New York: Harper \& Row Publisher.

Robert C. Beck, 1978. Motivation Theories and Principle, Now Jersey: Prentice Hall, Inc. 
Hurlock Elizabeth. 1994. Development Psychology Fifth Edition. New York: Me GrawHill. Book Company.

Hamalik Oemar. 1980. Metode Belajar dan Kesulitan Belajar. Bandung: Tarsito.

Kurt Singer, 1987. Membina Hasrat Belajar di Sekolah, Jakarta: CV. Remaja Karya.

Mc. Clelland, David, 1987. Human Motivaton, New York: Press Syndivate.

Muhibbin Syah. 1995. Psikologi Pendidikan dengan Pendidikan Baru. Bandung: Rosda Karya.

Muhadjir Noeng. 1995. Pengukuran Minat dan Kepribadian. Yogyakarta: Andi Offset.

Nana Sudjana, 1994. Penilaian Proses Belajar Mengajar, Bandung: Rosdakarya.

Nasution. 1992. Azas-azas Didaktik Metodologi Pengajaran dan Evaluasi. Jakarta: Bumi Restu,
Prijodarminto, Soegeng. 1992. Disiplin Menuju Sukses. Jakarta: Pradya Paramita.

Rohani, Ahmad. 2004. Pengelolaan Pengajaran. Jakarta: Rineka Cipta

Suryabrata Sumadi. 1985. Proses Belajar Mengajar di Perguruan Tinggi Jakarta: Andi Offset.

Sumargono. 1997. Metodologi Penelitian Pendidikan. Jakarta: Rineka Cipta.

Sudjana Surya. 1982. Pengantar Psikologi Pendidikan. IKIP Bandung,

Sudjana. 1990. Metode Statistika. Bandung: Tarsito.

Witherington, H.C. 1984. Psikologi Pendidikan, Terjemahan Muchtar Buchori, Jakarta: Aksara Baru.

Wechsler, 1988. Beliefs, Attitude and Value. San Francisco: Jossey-Bass Inc. Publishers. 